\title{
Parentification and Grandparents' Support from the Perspective of Grandchildren from Families of Various Structures ${ }^{1}$
}

\author{
Elżbieta Napora*
}

\begin{abstract}
The purpose of this study was to determine the strength of the relationship between a retrospective evaluation of the experienced social support given by grandparents and the material status of the family with the quality of life of the grown-up grandchildren in families of different structures. The formulated expectations have been verified with the Social Support Scale (SSS), Student's Life Satisfaction Scale (SLSS) and an individual personal survey. The obtained results show that in families of single mothers, the emotional and informative support offered by grandparents was a significant factor improving the quality of the life of the grandchildren. In a complete family, however, the significant forms of support from grandparents were esteem support and its other forms, except for informative support. Moreover, the material wealth of the original family was shown to be an important predictor of the evaluation of the quality of life of the grandchildren; it was judged more negatively by adolescent children of single mothers.

Key words: grandparents-grandchildren relationships, single mother families, quality of life of teenagers.
\end{abstract}

\section{Introduction}

Unfavourable conditions for the development of children and adolescents which are of a threat for their health and development (Borucka \& Ostaszewski, 2008)

* Elżbieta Napora, Institute of Philosophy, Sociology and Psychology, University Jan Dlugosz in Częstochova, Poland; e.napora@ajd.czest.pl

1 The elaboration was financed from the funds for the statutory activity DS/WNS/6038/2014 of the Sociology Department at Jan Dlugosz University in Częstochowa 


\section{Acta Technologica Dubnicae \\ volume 6, 2016, issue 1}

can lead to behavioral disorders. Protective factors, which prevent these disorders, can work against them.

Research shows that the help of the loved ones can be a protective factor. For a grandchild the feeling of emotional closeness with grandparents reduces the influence of a lowered maternal mood (Ruiz \& Silverstein, 2007). What can be of an example is a family in which a mother suffers from depression but its negative results are neutralized by good relations of a child with grandparents. It leads to lower probability of depression in the adult life of an offspring (Napora, Kozerska, \& Schneider, 2014). The bond between a grandchild with grandparents is an important additional protective factor apart from these which result from the existence of a social support chain, the outside family support as well as possessing high intelligence or the feeling of one's own value.

\section{Parentification and social support provided by grandparents}

Parentification of grandparents is a factor which protects a single mother family against the consequences of the difficulties connected with lonely motherhood (Napora et al., 2014). It can be a synonym of an unconditioned feeling, support and help. Hooper (2007) emphasizes that parentification takes place when there is a shift or change of roles. It can apply to a situation when a child plays a role of a parent, taking responsibility for the material and/ or emotional situation of other family members (as in: Schier, 2010). Other authors such as Chase define parentification as "a change of roles - functional, emotional or both in which a child sacrifices his own needs: the need of attention, security and gaining support in development in order to adjust and care about instrumental or emotional needs of a parent" (as in: Pasternak \& Schier, 2014).

The term of grandparents' parentification has not been used in literature so far. It applies to the relation between a child's parents and a child's grandparents and also to the relations between a grandchild and grandparents. Thus, by the term of parentification of grandparents one understands the expectation of an adult child family and support given by grandparents which is necessary for their proper functioning. However, analogically to a child's parentification, a shift of roles appears (Napora, Kozerska, \& Schneider, 2012). Grandparents are included in the parenthood sub-system and they play a role of a parent to a grandchild. They can also give support to one of the parents of a grandchild as it is given by a spouse. For example, in a single mother family parentification of grandparents is a situation in which they give support to a child and a mother in the scope it is realized by a father in full families. In conditions, such as death of grandchildren's father or dissolution of children's marriage, parentification of grandparents can be a positive phenomenon for both the grandparents 


\section{Acta Technologica Dubnicae \\ volume 6, 2016, issue 1}

themselves and for the other family members (Napora et al., 2014; Schneider, Napora, \& Kozerska, 2012). That is why, it is a protective factor and helps to recompense the negative consequences of the family members, which result from difficult life situations.

Parentification of grandparents manifests in, for example, giving support which in psychology is understood as an interaction undertaken by one or a few parties in a problem or difficult situation. What occurs in the process of interaction is not only the exchange of information but also emotional and instrumental exchange as well as exchange of tangible goods (Sęk, 1997). The exchange brings the participants of interaction closer to solve the problem and it serves a positive psychological function (Walęcka-Matyja, 2013). What is important for the effectiveness of social exchange is the correlation between the kind of support given and the needs of the receiver. Support is also about enhancing an individual in a stressful, decisive situation in which, without the support of others, he will not be able to overcome the difficulty (Sęk, 2001).

Lack of support, with the subjective feeling of loneliness, decreases both mental and physical resistance of a human being (Sęk, 1986). The effects of research show that among various components of social network, people give more meaning to emotional support than to current, specific help (Ball, 1983; Nowakowski, 2015).

So far what has been noticed was the factor of meaning and quality support from parents for the growing up child as a condition for his development. The quality of supporting social bonds is important for the mental development of adolescents who need help in the process of getting to know one another, in taking decisions and making choices. An individual who obtains high social support from the loved ones, can be characterized by the faith in the existence of social order, in the authority regulating legal, moral and social standards, in faith of the existence of values, in the reliability of friendship, and in faith that thanks to one's own behaviour, one can achieve a lot (compare Kmiecik-Baran, 2000). Early support of teenagers by grandparents positively correlates with their positive adjustment to life in further development stages and lack of mental disorders (Garmezy, Masten, \& Tellegen, 1984). Furthermore, these people deal much better in difficult situations (Jaworowska-Obój \& Skuza, 1986).

It has been proved that support of grandparents depends on the family needs (Baydar \& Brooks-Gunn, 1998; Hank \& Buber, 2009). The authors focusing on the research of a single mother family showed that a family characterized by a higher need, gets more support from grandparents than a full family. An unmarried mother, who needs additional support and who takes care of a child alone, gets more support than a married mother (Jendrek, 1993). It goes together 


\section{Acta Technologica Dubnicae \\ volume 6, 2016, issue 1}

with an observation that parents give more support to children who have additional difficulties. Bornat, Dimmock, Jones and Peace (1999) observed that in case of divorce, which is a traumatic situation, a strong bond between a divorcing mother and a grandmother appears. The grandmother's support is a defensive factor in the time of a crisis (Bornat et al., 1999). This research allows to draw a conclusion that the hypothesis saying that help and support of grandparents can play an important function in the mental and social functioning of adolescents is a right one (Schneider et al., 2012).

Grandparents disburden a single-mother from her core duties (Dex \& Ward, 2015), support her emotionally (Bornat et al, 1999) as well as her child (Bridges, Roe, Dunn, \& O'Connor, 2007). They tend to be willing to react when family problems appear, especially in case of health problems, teenage pregnancy, prison, and addiction to drugs, divorce, death of a family member (Pruchno, 1995). Thanks to grandparents' engagement in a family support, the family functions remain stable.

Research concerning the relation between the obtained social support or lack of it and the symptoms of depression among adolescents revealed considerable dependencies. The analysis of results obtained from 821 adolescents showed that a low level of social support from the parent's site is prospectively linked with depression symptoms. This suggests that family environment is an inseparable source of support in comparison with the support from the peers (Khatib, Bhui, \& Stansfeld, 2013).

Research conducted in Poland on a group of more than 500 researched adolescents by means of a Social Support Scale revealed that in a single mother family every kind of support: informational, instrumental, evaluating, emotional given both by a grandmother and a grandfather from the mother's side, is more favorably assessed by granddaughters than grandsons. In two-parent families it is the granddaughters who are more satisfied with the informational, evaluating and emotional support of a maternal grandmother and only informational support of a paternal grandmother (Napora, 2015).

Despite crucial positive effects resulting from support and help of grandparents for the functioning of a full family and a single mother family, this issue is not systematically analyzed, remaining still a neglected aspect of research. Therefore, the research has been undertaken, which conformed to domestic and international initiatives allowing us to diagnose various aspects of life quality that are recommended by the EU and concern intergenerational family support. The results of the collected data are part of a bigger interregional and interdisciplinary project realized in cooperation with the Faculty of Pedagogy of Jan Dlugosz University in Częstochowa, National Measurement Laboratory in 


\section{Acta Technologica Dubnicae \\ volume 6, 2016, issue 1}

New South Wales, Australia and the Faculty of Pedagogy of Marie CurieSklodowska University (Napora, Kozerska, \& Miszczak, 2014; Kozerska, Miszczak, \& Napora, 2015). Little research on the topic of the meaning of grandparents' engagement in the functioning of a family, not only the single mother's one, led to analysis which allowed to compare the relations which occur between the social support of grandparents and the life quality of grandchildren. The obtained results will serve to enrich the explanations connected with the issues concerning family functioning and they will allow us to take a viewpoint on the argument which says that grandparents' support plays an important role in the mental and social functioning of adolescents.

Earlier analysis concerning the evaluation of relations in terms of closeness and frequency showed that higher average results for the evaluation of a relation with a maternal grandfather (from the mother's side), expressed by grandchildren from a single mother family show a steady, high activity and attachment to this grandfather. Taking into consideration the analogical assessments concerning the relations with a maternal grandmother, what can be observed is that similar motivation accompanies her efforts as well. These results make us conclude that in a single mother family maternal grandparents are significantly more parentified than the paternal ones (Napora, 2016).

The aim of the research was to capture the strength of bonds between a retrospective evaluation of the social support experienced from the grandparents' side and the quality of grandchildren's life as well as to illustrate life quality of adolescents in terms of a family's material status. What was measured was the social support level whose source are the maternal and paternal grandparents, assessed by grandchildren. The research problems were formed in two questions. The first one: is there a connection between a social support of grandparents in the grandchildren's retrospective assessment and the life quality and if so, is this connection statistically significant? The second question: what are the other factors connected with a family which can explain the adolescents' life quality? The effects allowed us to comment on the hypothesis:

H1: What can be definitely more frequently observed is the meaningful relation between social support of grandparents and the life quality of grandchildren in a single mother family than in a full family. In this hypothesis it is expected that grandchildren assess the relations with a grandmother better - what has been earlier mentioned - that is why, what was expected was the more favourable evaluation of a social support from her side and the connection of this support with life quality of adolescents (Sęk, 1986), especially in single mother families. $\mathrm{H} 2$ : Regardless of the family structure, life quality of grandchildren will significantly depend on the evaluation of a family's material status. This expectation is proved by the research presumption (Cudak, Kowolik, \& Pindera, 1999) and report analysis in which it is emphasized that a crucial parameter for 


\section{Acta Technologica Dubnicae \\ volume 6, 2016, issue 1}

the family's life quality are the material conditions of a family (Bieńkuńska, Piasecki, Verger, \& Lebrere, 2013).

\section{Research Methods}

\section{1 Research sample}

The research was conducted on a sample of students from the Częstochowa subregion. It was carried out from January 2013 to May 2013 and at the beginning of 2014, with the approval of students who were informed about the possibility of pausing while fulfilling the questionnaires without any consequences. 206 people took part in the research. During the statistical analysis 10 questionnaires were not taken into account; they were rejected due to omitting some statements or owning to the fact that the students came from single father families.

Table 1

Structure of the researched adolescents

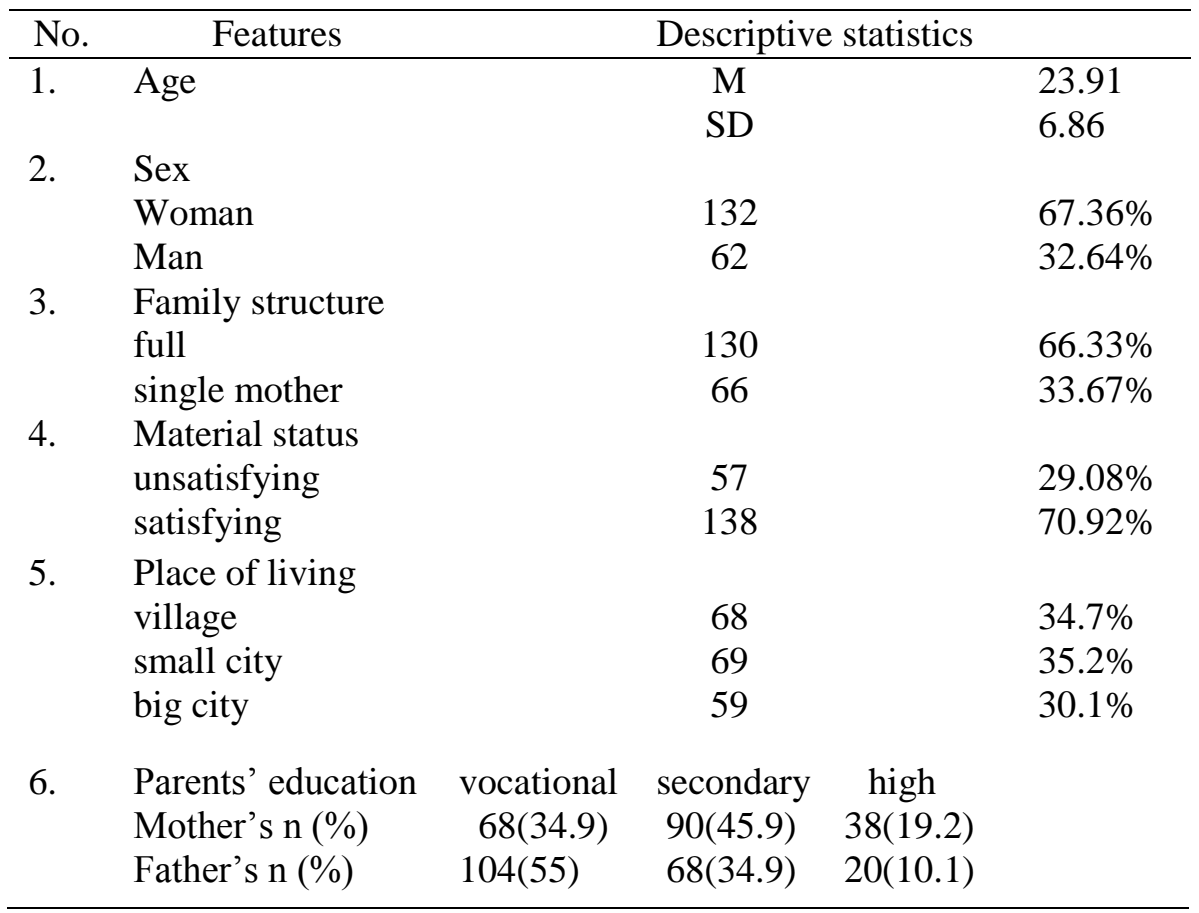

The average age of the researched was 23.91, among the people women dominated $(\mathrm{n}=132,67.34 \%)$. The biggest number of participants came from 


\section{Acta Technologica Dubnicae \\ volume 6, 2016, issue 1}

small cities $(n=69,35.2 \%)$ and from full families $(n=130,66.32 \%)$. The wellbeing of a family was evaluated on a satisfactory level by $70.4 \%(n=138)$ of the researched sample. The research was carried out according to the table of meetings and it was organized after the arrangement with both the university authorities and students.

\subsection{Measurement}

The tools which are the basis for the analysis and conclusions are scales and questionnaires. The Social Support Scale (SSS) in the adaptation of KmiecikBaran (2000) was used to measure social support. This scale is divided into 4 parts which consist of questions to which a researched person refers in a 4degree scale evaluating in a retrospective manner the degree of genuineness of the particular statements to him. The psychometric qualities of the scale are satisfying, reliability of SSS is approximate to unity (tests with a factor 0.75 are considered reliable). SSS includes statements which refer to four categories of support: informational, instrumental, evaluating and emotional. 4 statements for each kind ( 3 positive statements and 1 negative one). The students participating in the research were asked to assess, by means of a few-degree scale, the extent to which a given statement refers to him, 3 - 'yes' - a statement very strongly fulfilled with this kind of support; 2 - 'rather yes' - a statement strongly fulfilled with a given sort of support; 1 - 'rather no' - a statement weakly fulfilled with a given sort of support, 0 - 'no, does not apply' - a statement which is not fulfilled with a given sort of support at all. Additionally, one can measure the general level of social support.

Huebner Scale SLSS (Student's Life Satisfaction Scale) served to assess life quality. It is a tool used, for example, in research concerning life satisfaction of secondary school pupils (Oblacińska \& Woynarowska, 2006), life quality of adolescents (Napora et. al., 2014; Napora, 2016), life quality of seniors (Szornak, Kurhalyuk, Tkachenko, \& Pałaczyńska, 2010). The scale consists of seven statements concerning aspects of general life quality, that is: evaluation of style, life satisfaction, and interpersonal satisfaction. By means of a 6-degree scale the researched evaluated the extent to which each statement refers to his life until now (0 - 'I definitely do not agree', 1 - 'I do not agree', 2 - 'rather no', 3 - 'difficult to say', 4 - 'rather yes', 5 - 'I definitely agree').

By contrast, by means of a questionnaire, socio-demographic data were collected. That is: age, sex, place of living, family structure, level of parents' education, material status of a family.

Tools were selected by a research team which consisted of a few family researchers from disciplines such as psychology, pedagogy, human development and sociology who came from the following institutions Jan Dlugosz University 


\section{Acta Technologica Dubnicae \\ volume 6, 2016, issue 1}

in Częstochowa, National Measurement Laboratory in New South Wales, Australia and Marie Curie-Sklodowska University in Lublin. The team met for seminars in order to discuss the scope and strategy of conducting research, train the pollsters and continue consulting if any doubts during the whole process of data collection appeared. The aim of the created interdisciplinary team was to combine research environment, disciplines and experience of the researchers.

\section{Results}

In order to verify the hypothesis non-parametric methods were used. To make the comparisons between two groups U Mann-Whitney test was applied. To analyze the relations between variables, coefficient of Spearman range correlations as well as chi-squared test were used.

\subsection{Social support and life quality of grandchildren}

The scales allowed us to collect the evaluations submitted by the participants of the study concerning social support from the grandparents' side and referring to the assessment of life quality. What was checked was the relation between the evaluation of social support and life quality. The basis for the division of the researched into two groups was the criteria of family structure background. The obtained coefficient of Spearman rang correlation $(\mathrm{R})$ is included in tables 2 and 3.

Table 2

Connection of R-Spearman between support of maternal grandparents and grandchildren's life quality

\begin{tabular}{llccccccc}
\hline $\begin{array}{c}\text { Social } \\
\text { support }\end{array}$ & Family & \multicolumn{5}{c}{ Maternal grandparents } \\
structure & \multicolumn{2}{c}{ Grandmother } & \multicolumn{4}{c}{ Grandfather } \\
\hline \multirow{3}{*}{ Informational } & & $\mathrm{R}$ & $\mathrm{t}(\mathrm{N}-2)$ & $p$ & $\mathrm{R}$ & $\mathrm{t}(\mathrm{N}-2)$ & $p$ \\
& Full & 0.151 & 1.607 & 0.110 & 0.108 & 1.058 & 0.292 \\
Instrumental & Single mother & -0.012 & -0.092 & 0.926 & 0.061 & 0.449 & 0.655 \\
& Full & 0.111 & 1.174 & 0.242 & 0.075 & 0.747 & 0.456 \\
Evaluating & Single mother & -0.150 & -1.159 & 0.251 & 0.041 & 0.304 & 0.762 \\
& Full & 0.081 & 0.856 & 0.393 & 0.114 & 1.133 & 0.259 \\
& Single mother & -0.193 & -1.515 & 0.135 & -0.009 & -0.070 & 0.944 \\
Emotional & Full & 0.133 & 1.417 & 0.159 & 0.103 & 1.032 & 0.304 \\
& Single mother & -0.013 & -0.105 & 0.916 & 0.038 & 0.280 & 0.779 \\
General & Full & 0.118 & 1.250 & 0.213 & 0.096 & 0.934 & 0.352 \\
& Single mother & -0.042 & -0.321 & 0.748 & 0.079 & 0.576 & 0.567 \\
\hline
\end{tabular}




\section{Acta Technologica Dubnicae \\ volume 6, 2016, issue 1}

Both in full families and single mother families, no crucial relation between grandchildren's life quality and maternal grandparents' social support was observed. The subjective grandparents' social support experienced by grandchildren is crucially connected with life quality of adolescents. This suggests that maternal grandparents are similarly evaluated by the rich ones in terms of the social support given. What surprises, however, is the direction of the occurring dependencies. In a single mother family a small statistically not important negative relation between every kind of social support of a grandmother, evaluative support of maternal grandfather and the life quality of grandchildren occurred.

Table 3

Connection of $R$-Spearman between support of paternal grandparents and grandchildren's life quality

\begin{tabular}{llllrrrr}
\hline \multicolumn{1}{c}{$\begin{array}{c}\text { Social } \\
\text { support }\end{array}$} & \multicolumn{1}{c}{$\begin{array}{c}\text { Family } \\
\text { structure }\end{array}$} & \multicolumn{5}{c}{ Grandmother } & \multicolumn{3}{c}{ Grandfather } \\
& & $\mathrm{R}$ & $\mathrm{t}(\mathrm{N}-2)$ & $p$ & $\mathrm{R}$ & $\mathrm{t}(\mathrm{N}-2)$ & $p$ \\
\hline Informational & Full & 0.071 & 0.754 & 0.451 & 0.057 & 0.528 & 0.598 \\
& Single mother & 0.104 & 0.790 & 0.432 & 0.240 & 1.737 & 0.088 \\
Instrumental & Full & 0.147 & 1.568 & 0.119 & 0.178 & 1.644 & 0.103 \\
& Single mother & 0.078 & 0.587 & 0.559 & 0.188 & 1.344 & 0.184 \\
Evaluating & Full & 0.206 & 2.228 & 0.027 & 0.257 & 2.394 & 0.018 \\
& Single mother & -0.021 & -0.160 & 0.873 & 0.119 & 0.840 & 0.404 \\
Emotional & Full & 0.218 & 2.355 & 0.020 & 0.217 & 2.020 & 0.046 \\
& Single mother & 0.128 & 0.967 & 0.337 & 0.247 & 1.789 & 0.079 \\
General & Full & 0.178 & 1.898 & 0.060 & 0.198 & 1.822 & 0.072 \\
& Single mother & 0.086 & 0.650 & 0.517 & 0.255 & 1.852 & 0.069 \\
\hline
\end{tabular}

A significant positive relation was obtained between life quality of grandchildren from a full family and evaluating support of a grandmother $(\mathrm{R}=$ 0.206; $\mathrm{p}<0.027)$ as well as emotional $(\mathrm{R}=0.218 ; \mathrm{p}<0.02)$ and general support $(\mathrm{R}=0.178 ; \mathrm{p}<0.06)$. What was also observed was the important connection between grandchildren's life quality and the evaluating support expressed by a grandfather $(\mathrm{R}=0.257 ; \mathrm{p}<0.018)$ as well as emotional $(\mathrm{R}=0.217 ; \mathrm{p}<0.046)$ and general support $(\mathrm{R}=0.198 ; \mathrm{p}<0.072)$. The obtained results allow us to assume that what is the most important for the subjective evaluation of grandchildren's life quality from a full family is the evaluating, emotional and general support of both grandmother and grandfather from the father's side. 


\section{Acta Technologica Dubnicae \\ volume 6, 2016, issue 1}

Yet in a single mother family positive crucial connections on the level of statistical tendencies were revealed. The dependencies occur between the informational support given by a grandfather $(\mathrm{R}=0.24 ; \mathrm{p}<0.088)$, the emotional one $(\mathrm{R}=0.247$; $\mathrm{p}<0.079)$, the general one $(\mathrm{R}=0.255 ; \mathrm{p}<0.069)$ and life quality of grandchildren. Grandmother's support is without any meaning for the evaluation of life quality by grandchildren. The results allow us to assume that what is the most important for the subjective evaluation of life quality of grandchildren from a single mother family is the informational, emotional and general support but only from the father's side.

\subsection{Life quality and the material status of a family}

The intra-group analysis (see Table 4 and Table 5) and the intergroup analysis (Table 6) carried out on the researched from various structures allowed to capture the difference in the evaluation of life quality in terms of material status of a family. ${ }^{2}$

Table 4

Descriptive statistics together with the relevance test for the life quality of grandchildren from single mother families

\begin{tabular}{lccccccccc}
\hline $\begin{array}{l}\text { Variable } \\
(\mathrm{N}=66)\end{array}$ & $\mathrm{M}$ & $\mathrm{Me}$ & Min. & Max. Quartile Quartile & $\mathrm{SD}$ & $z$ & $p$ \\
\hline $\begin{array}{l}\text { Satisfactory } \\
(\mathrm{n}=37)\end{array}$ & 25.43 & 26 & 10.00 & 34.00 & 22.00 & 29.00 & 5,78 & & \\
& & & & & & & & 2,749 & 0,005 \\
$\begin{array}{l}\text { Unsatisfactory } \\
(\mathrm{n}=29)\end{array}$ & 21.32 & 22 & 9.00 & 32.00 & 17.00 & 25.00 & 5,64 & & \\
\hline
\end{tabular}

A strong dependency between the assessment of life quality and a family material status was observed. Grandchildren from a single mother family, more satisfied with the material family status assessed their life quality better $(\mathrm{z}=$ $2.749 ; \mathrm{p}=0.005$ ) than those who were dissatisfied with it.

\footnotetext{
${ }^{2}$ The people with the mark of good and very good were included in the category of people evaluating the material level of family as the satisfying one. People with the mark satisfactory and unsatisfactory were included in the category of people who asses the material level as the unsatisfying one
} 


\section{Acta Technologica Dubnicae \\ volume 6, 2016, issue 1}

Table 5

Descriptive statistics together with the relevance test for the life quality of grandchildren from full families

\begin{tabular}{llllllllll}
\hline $\begin{array}{l}\text { Variable } \\
(\mathrm{N}=129)\end{array}$ & $\mathrm{M}$ & $\mathrm{Me}$ & Min. & Max. Quartile & $\begin{array}{l}\text { Luartile } \\
\text { QD }\end{array}$ & $z$ & $p$ \\
\hline $\begin{array}{l}\text { Satisfactory } \\
(\mathrm{n}=101)\end{array}$ & 26.17 & 27 & 11.00 & 35.00 & 23.00 & 30.00 & 5.19 & & \\
$\begin{array}{l}\text { Unsatisfactory } \\
(\mathrm{n}=28)\end{array}$ & 23.07 & 25 & 9.00 & 30.00 & 19.50 & 27.00 & 5.36 & & \\
\hline
\end{tabular}

What was also observed was the strong dependency between the assessments of life quality and material status of a family. Grandparents from full families being more satisfied with their material status evaluated their life quality much better $(\mathrm{z}=2.641 ; \mathrm{p}=0.008)$ than the unsatisfied ones.

Table 6

Descriptive statistics together with relevance test for the differences in adolescents' life quality in terms of a family structure

\begin{tabular}{|c|c|c|c|c|c|}
\hline \multirow{3}{*}{$\begin{array}{l}\text { Family material } \\
\text { status }\end{array}$} & \multicolumn{4}{|c|}{ Family structure } & \multirow{3}{*}{ Total } \\
\hline & \multicolumn{2}{|r|}{ single mother } & \multicolumn{2}{|c|}{ full } & \\
\hline & $\mathrm{n}$ & $\%$ & $\mathrm{n}$ & $\%$ & \\
\hline Unsatisfactory & 29 & 43,94 & 28 & 21,71 & 57 \\
\hline Satisfactory & 37 & 56,06 & 101 & 78,29 & 138 \\
\hline Total & 66 & 100,00 & 129 & 100,00 & 195 \\
\hline Value $\chi^{2}$ & \multicolumn{4}{|c|}{10,142} & \\
\hline$D F$ & \multicolumn{4}{|c|}{1} & \\
\hline$p$ & \multicolumn{4}{|c|}{0,001} & \\
\hline
\end{tabular}

In single mother families there is a significantly higher percentage of adolescents who evaluate their material status as the unsatisfactory one. The obtained result proved to be statistically significant $\left(\chi^{2}=10.142 ; \mathrm{DF}=1 ; \mathrm{p}=0.001\right)$. The result suggests that a bit lower material status in a single mother family could influence the lower life quality. 


\section{Acta Technologica Dubnicae \\ volume 6, 2016, issue 1}

\section{Discussion and conclusions}

The aim of the elaboration was to take a position on two research problems. The first problem is whether there is a connection between the social support of grandparents and life quality in the retrospective evaluation of grandchildren, and if so, is this connection statistically significant? In the light of the obtained results, one can say that no relevant dependencies for the maternal grandparents, both in a single mother family as well as the full family, were observed (Table 2). According to the possessed knowledge from other research on social support, it was expected that the result could be less favourable for the grandchildren from full families. Thereby, the formed expectation that support from maternal grandparents will more crucially connect with the life quality of grandchildren in a single mother family than in a full family (H1), was not proved with the collected empirical material. It can be assumed that grandparents could aim their social support at their children and not directly at grandchildren and hence, social support did not have an important influence on their life quality.

However, the obtained results allow to claim that for the evaluation of life quality of grandchildren in single mother families what proved to be of importance was the emotional $(\mathrm{p}=0.079)$, informational $(\mathrm{p}=0.088)$ and general support $(\mathrm{p}=0.069)$ of only a paternal grandfather (table 3$)$. Yet in a full family a few significant positive connections between the social support of paternal grandparents and the life quality of grandchildren were obtained. The results showed significant connections between evaluating support $(p=0.027)$, emotional $(p=0.02)$ and a general one $(p=0.06)$ of a paternal grandmother and grandfather (respectively: $\mathrm{p}=0.018 ; \mathrm{p}=0.046 ; \mathrm{p}=0.072$ ) and the grandchildren's life quality. The results do not confirm the earlier results obtained from a group of grandchildren from Lublin and Śląsk Voivodeships in which there was a meaningful relation between the evaluating support of a maternal grandfather in a single mother family and crucial relations between every sort of support of maternal grandparents in a full family (Napora et. al., 2014, p. 168).

Both emotional and evaluating support is the kind of psychological help, which strengthens the feeling of value among adolescents and reveals positive attitude of adults towards them. Generally, both forms of support are about sending verbal and non-verbal messages which ensure closeness. These messages occur most commonly and they are mostly awaited. Informational (cognitive) support comes down to the exchange in the process of information interaction which fosters a better understanding of a situation and a problem. It is about giving advice and information which can help in solving problems. It is important to pass feedback information about the efficiency of the undertaken actions. Social support expressed by grandmothers in emotional and evaluating scope is mainly 


\section{Acta Technologica Dubnicae \\ volume 6, 2016, issue 1}

expressed in the aspect of a sex stereotype. According to it, women are more aimed at building social bonds and they are more emotionally open (Cavanaugh, 1997). It is contradicted by the obtained results for the connections between evaluation of social support and life quality of grandchildren from a single mother family (table 3), in which the social support given shows a negative relation with life quality of grandchildren. Yet close emotional bond of a parental grandfather with grandchildren, their informational, emotional and general support shows a meaningful connection with their life quality. As researchers suggest, it can be a consequence of allegiance relation which was created between them (Tyszkowa, 1991).

Therefore, a conclusion can be formulated that there are no significant relations between social support by maternal grandparents and the quality of life of grandchildren both in two-parent and in single-mother families. The evaluations of social support provided by grandparents that the grandchildren submitted during the study are similar to each other. This conclusion does not apply to the evaluation of social support of a paternal grandfather, which clearly shows the connection between the life qualities of grandchildren regardless of family structure. This suggests that if a parental grandfather engages in help and support of grandchildren, especially in a single mother family, he will thereby contribute to the better life satisfaction. He can act like a shield for grandchildren experiencing changes in a family structure. The conclusion contradicts the observations that grandchildren usually have better relations with maternal grandparents rather than the paternal ones (Hodgson, 1992). What is more, paternal grandmothers influence life quality of grandchildren but only in a full family.

The obtained results allow us to think that adolescents who come from full families evaluate grandparents' support better than the adolescents who come from single mother families. In full families more results which were statistically significant for the relation between the social support evaluation of grandparents and life quality of grandchildren were obtained. These results suggest that if there is involvement from the distant family members (of a grandmother and grandfather), the mental well-being of children's upbringing improves as well. The results show that there are differences in the evaluation of grandmother's and grandfather's support caused by the distinctness of family structures - in full families relations with grandparents happen quite harmoniously and they are highly assessed by grandchildren, yet in single mother families if the intensification of contacts with a parental grandfather appears, then life quality of grandchildren clearly increases. It can suggest that higher engagement, especially of a grandfather in paternal line, results in the increased mental wellbeing of grandparents in these types of families. This statement should refer to the observations described in literature where grandparents give their advice 


\section{Acta Technologica Dubnicae \\ volume 6, 2016, issue 1}

concerning learning, work and finance. The obvious expectations would be a counterbalanced influence of grandparents - both from the maternal and paternal line - which would without doubt contribute to the better fulfillment of grandchildren's needs and which would find the reflection in adolescents' evaluation on the topic of their life quality until now.

Answering the second question, of what factors connected with family additionally allow us to describe the quality of life of grandchildren, it can be said, on the basis of intergroup analysis, that life quality of grandchildren is significantly connected with the material status of a family (table 4 and 5), regardless of the family structure. Adolescents unsatisfied with the economic well-being of their family evaluated their life quality low. Moreover, in single mother families a higher percentage of adolescents evaluating the material family status as the unsatisfying (43.94\%) in comparison with the researched people from full families $(21.71 \%)$ was observed. The obtained result for the inter-group comparison is statistically significant $(\mathrm{p}=0.001)$ (Table 6) and it suggests that what could influence the lower life quality in a single mother family is the fact of a bit lower material status.

Effects prove that low material status of a family is constantly seen by adolescents and it can lead to deprivation of mental needs: affiliation, meaningless, recognition in the eyes of others and it additionally solidifies passive and aggressive attitude in interpersonal relations (Siwek, 2010). As a result, it can lead to lowering the meaning and withdrawal from the engagement in social life (Buhs and Ladd, 2001). Worse material family situation can result in social exclusion of adolescents.

To conclude, the obtained results indicate:

1. Similarity in experiencing social support of maternal grandfathers by grandchildren, regardless of the family structure of dwelling in Częstochowa sub-region.

2. More crucial relations between the social support (evaluating, emotional, general) of paternal grandmother and grandfather and life quality of grandchildren in full families.

3. The surprising result for the positive low connection between social support (informational, emotional and general) of a paternal grandfather and life quality of grandchildren in a full family.

4. Unsatisfied adolescents due to the material status, regardless of family structure, evaluate their life quality considerably worse. What is more, in comparison with adolescents from full families, a twice higher percentage of adolescents from single mother families were unsatisfied with their material status. 


\section{Acta Technologica Dubnicae \\ volume 6, 2016, issue 1}

The results allow us to assume that the most important for the subjective evaluation of life quality of grandchildren from a single mother family is the informational, emotional and general support only of a paternal grandfather. In a full family evaluating, emotional and general support both of a paternal grandmother and grandfather is positively connected with the life quality of adolescents.

To conclude, the visible and experienced social support of parental grandparents fosters life satisfaction of adolescents who come from Częstochowa sub-region. Furthermore, results suggest that a lower material status influences lower life quality in a single mother family. With the higher material status of a family, higher life satisfaction of adolescents can be observed.

\section{References}

Ball, R. E. (1983). Family and Friends: A Supportive Network for Low-Income American Black Families. Journal of Comparative Family Studies, 14, pp. $51-65$.

Baydar, N., \& Brooks-Gunn, J. (1998). Profiles of grandmothers who help care for their grandchildren in the United States. Family Relations, 47(4), 385393.

Bieńkuńska, A., Piasecki, T., Verger, D., \& Lebrère, A. Jakość życia. In D. VERGER, A. LEBRÈRE (Eds.), Jakość życia, kapitat społeczny, ubóstwo $i$ wykluczenie społeczne $w$ Polsce. Retrieved from: http://stat.gov.pl/cps/rde/xbcr/gus/WZ_jakosc_zycia_2013.pdf

Bornat, J., Dimmock, B., Jones, D., \& Peace, S. (1999). Stepfamilies and older people: Evaluating the implications of family change for an ageing population. Ageing and Society, 19, 239-261.

Borucka, A., \& Ostaszewski, K. (2008). Koncepcja resilience. Kluczowe pojęcia i wybrane zagadnienia. Medycyna Wieku Rozwojowego, 12(2), 587-597.

Bridges, L. J., Roe, A. E. C., Dunn, J., \& O’Connor, T. G. (2007) Children's perspectives on their relationships with grandparents following parental separation: a longitudinal study. Social Development, 16(3), 539-554. doi: 10.1111/j.1467-9507.2007.00395.x

Buhs, E. S., \& Ladd, G. W. (2001). Peer Rejection as an Antecedent of Young Children's School Adjustment. An Examination of Mediating Processes. Development Psychology, 24, 815-823.

Cavanaugh, J. (1997). Starzenie się. In P. E. Bryant \& A. M. Colma (Eds.), Psychologia rozwojowa (pp. 109-132). Poznań: Publishing House Zysk i Ska. 
Cudak, H., Kowolik, P., \& Pindera, M. (1999). Subiektywne i obiektywne ubóstwo materialne w rodzinie polskiej. Auxilium Sociale - Wsparcie Spoleczne, 3-4, 165-172.

Dex, S., \& Ward, K. Parental care and employment in early childhood, an analysis of the Millennium Cohort Study Sweeps 1 and 2. Retrieved from: http://www.fatherhoodinstitute. org/uploads/ publications/257.pdf

Garmezy, N., Masten, A. S., \& Tellegen, A. (1984). The study of stress and competence in children: A building block for developmental psychopathology. Child Development, 55, 97- 111.

Hand, K., \& Buber, I. (2009). Grandparents Caring for Their Grandchildren Findings From the 2004 Survey of Health, Ageing, and Retirement in Europe. Journal of Family Issues, 30, 53-73. doi: 10.1177/0192513X08322627

Hodgson, L. G. (1992). Adult grandchildren and their grandparents: The enduring bond. International Journal of Aging and Human Development, 34(3), 209-225. doi: 10.1177/0192513 01022004002

Jaworowska-Obój, Z., \& Skuza, B. (1986). Pojęcie wsparcia społecznego i jego funkcje w badaniach naukowych. Przeglad Psychologiczny, 3, pp. 733-745.

Jendrek, M. P. (1993). Grandparents Who Parent Their Grandchildren - Effects on Lifestyle. Journal of Marriage and the Family, 3(55), 609-621.

Khatib, Y., Bhui, K., \& Stansfeld, S. A. (2013). Does social support protect against depression \& psychological distress? Findings from the relachs study of East London adolescents. Journal of Adolescence, 36(2), 393-402. doi: 10.1016/j.adolescence.2013.01.001

Kmiecik-Baran, K. (2000). Narzędzia do rozpoznawania zagrożeń społecznych w szkole. Gdańsk: Publishing House Przegląd Oświatowy.

Kozerska, A., Miszczak, E., \& Napora, E. (2015). Zaangażowanie dziadków w ocenie wnuków z rodzin samotnych matek. Kultura i Edukacja, 1(7), pp. 231-246. doi: 10.15804/kie.2015.01.12

Napora, E. (2016). Relacje z dziadkami a jakość życia wnuków w rodzinach o różnej strukturze. Polskie Forum Psychologiczne, 21(1), 5-22. DOI: 10.14656/PFP20160101

Napora, E. (2015). Parentyfikacja dziadków warunkiem bezkonfliktowości w rodzinach o różnej strukturze. In D. Borecka-Biernat (Ed.), Sytuacja konfliktu spolecznego. Przyczyny - Sposoby rozwiazywania - Skutki. Seria Prace Psychologiczne (pp. 83-94). Wrocław: Publishing House Uniwersytet Wrocławski.

Napora, E., Kozerska, A., \& Schneider, A. (2012). Can Deprived Post-industrial Rural and Small Town Communities Become Ecologically Sustainable? A Study of Resilience in Adolescents from Single Mother Families in the Northern Subregion of Silesia in the South of Poland. Poster, International Conference, Amsterdam. 
Napora, E., Kozerska, A., \& Schneider, A. (2014). Parentyfikacja dziadków czynnikiem resilience $\mathrm{w}$ funkcjonowaniu rodziny samotnej matki przegląd badań. Kultura i Edukacja, 1(101), 51-71.

Napora, E., Kozerska, A., \& Miszczak, E. (2014). Wsparcie dziadków w rodzinie o różnej strukturze a jakość życia młodzieży. Acta Humanica, 2, 161-170.

Nowakowski, M. (2015). Pojęcie wsparcia społecznego $i$ problemy jego pomiaru ze szczególnym uwzględnieniem populacji seniorów. Retrieved from: http://dspace.uni.lodz.pl:8080/xmlui/bitstreamhandle/11089/3695/32. $\% 20$ Nowakowski.pdf?sequence $=1$

Oblacińska, A., \& Woynarowska, B. (Eds.). (2006). Zdrowie subiektywne, zadowolenie $z$ życia $i$ zachowania zdrowotne uczniów szkót ponadgimnazjalnych $w$ Polsce $w$ kontekście czynników psychospołecznych $i$ ekonomicznych. Raport z badań. Warszawa: Instytut Matki i Dziecka.

Pasternak, A., \& Schier, K. (2014). Życie bez dzieciństwa - parentyfikacja u kobiet z syndromem DDA. Psychiatria Polska, 48(3), 553-562.

Pruchno, R. (1995). Grandparents in American Society: Review of Recent Literature. Retrieved from: http://files.eric.ed.gov/fulltext/ED413977.pdf

Ruiz, S. A., \& Silverstein, M. (2007). Relationships with grandparents and the emotional well-being of late adolescent and young adult grandchildren. Journal of Social Issues, 63(4), 793-808. doi: 10.1111/j.15404560.2007.00537.x

Schier, K. (2010). Gdy dziecko staje się rodzicem - odwrócona troska, czyli zjawisko parentyfikacji w rodzinie. In B. Tryjarska (Ed.), Bliskość $w$ rodzinie (pp. 63-80). Warszawa: Publishing House Scholar.

Schneider, A., Napora, E., \& Kozerska, A. (2012). Parentyfikacja dziadków jako czynnik wpływający na resilience $w$ rodzinie samotnej matki $w$ prowincjonalnej Polsce - zapowiedź badań. In M. Komorska (Ed.), Seniorzy i mlodzi we wspólnej przestrzeni społecznej (pp. 84-95). Lublin: Publishing House UMCS.

Sęk, H. (2001). O wieloznacznych funkcjach wsparcia społecznego. In I. Cierpiałkowska and H. Sęk (Eds.), Psychologia kliniczna i psychologia zdrowia (pp. 13-32). Poznań: Publishing House Fundacja Humanior.

Sęk, H. (1997). Rola wsparcia społecznego w sytuacji kryzysu. In D. KubackaJasiecka, A. \& Lipawska -Teutsch (Eds), Oblicza kryzysu psychologicznego i pracy interwencyjnej (pp. 143-158). Kraków: Publishing House All.

Sęk, H. (1986). Wsparcie społeczne - co zrobić, aby stało się pojęciem naukowym? Przegląd Psychologiczny, 3, 791-799.

Siwek, S. (2010). Czynniki społeczne w genezie nieprawidłowego rozwoju i zachowania. Acta Universitatis Lodziensis Folia Psychologica, 14, 19-43.

Szornak, M., Kurhalyuk, N., Tkachenko, T., \& Pałczyńska, K. (2010). Ocena zależności miedzy satysfakcją życia a stanem zdrowia ludzi w podeszłym wieku. In N. Kurhalyuk \& P. Kamiński (Eds.), Ekofizjologiczne 


\section{Acta Technologica Dubnicae volume 6, 2016, issue 1}

uwarunkowania zdrowia czlowieka (pp. 100-113). Słupsk: Słupski Uniwersytet Trzeciego Wieku.

Tyszkowa, M. (1991). Społeczne role babci i dziadka w rodzinie. Problemy Rodziny, 1, 11-20.

Walęcka-Matyja, K. (2013). Indywidualizm adolescenta a system wspólnoty rodzinnej w perspektywie psychologicznej. Horyzonty Wychowania, 24, 37 58 . 